\title{
Identifying marine pelagic ecosystem management objectives and indicators
}

\author{
Trenkel Verena ${ }^{1, *}$, Hintzen Niels T. ${ }^{2}$, Farnsworth Keith D. ${ }^{3}$, Olesen Christian ${ }^{4}$, Reid David ${ }^{5}$, \\ Rindorf Anna ${ }^{6}$, Shephard Samuel ${ }^{3}$, Dickey-Collas Mark ${ }^{7}$
}

\author{
${ }^{1}$ Ifremer, rue de l'île d'Yeu, BP21105, 44311 Nantes Cedex 3, France \\ 2 IMARES, Part of Wageningen UR, Institute for Marine Resources and Ecosystem Studies, PO Box 68, \\ IJmuiden 1970 AB, The Netherlands \\ ${ }^{3}$ School of Biological Sciences, Queen's University Belfast, 97 Lisburn Road, Belfast BT9 7BL, UK \\ ${ }_{5}^{4}$ Danish Pelagic Producers Organisation, H.C. Andersens Boulevard 37, 1553 Copenhagen, Denmark \\ ${ }^{5}$ Irish Marine Institute, Galway, Republic of Ireland \\ ${ }^{6}$ National Institute of Aquatic Resources, Technical University of Denmark, Jægersborg Allé 1, 2920 \\ Charlottenlund, Denmark \\ ${ }^{7}$ ICES, H.C. Andersens Boulevard 44-46, 1553 Copenhagen, Denmark \\ * Corresponding author : Verena Trenkel, Tel.: +33 240374000 ; \\ email address : verena.trenkel@ifremer.fr
}

\begin{abstract}
:
International policy frameworks such as the Common Fisheries Policy and the European Marine Strategy Framework Directive define high-level strategic goals for marine ecosystems. Strategic goals are addressed via general and operational management objectives. To add credibility and legitimacy to the development of objectives, for this study stakeholders explored intermediate level ecological, economic and social management objectives for Northeast Atlantic pelagic ecosystems. Stakeholder workshops were undertaken with participants being free to identify objectives based on their own insights and needs. Overall 26 objectives were proposed, with $58 \%$ agreement in proposed objectives between two workshops. Based on published evidence for pressure-state links, examples of operational objectives and suitable indicators for each of the 26 objectives were then selected. It is argued that given the strong species-specific links of pelagic species with the environment and the large geographic scale of their life cycles, which contrast to demersal systems, pelagic indicators are needed at the level of species (or stocks) independent of legislative region. Pelagic community indicators may be set at regional scale in some cases. In the evidence-based approach used in this study, the selection of species or region specific operational objectives and indicators was based on demonstrated pressurestate links. Hence observed changes in indicators can reliably inform on appropriate management measures.
\end{abstract}




\section{Highlights}

- Stakeholder consultation for listing pelagic ecosystem management objectives. Pressures-state link used to identify operational objectives and indicators. Population level was found important for marine pelagic communities.

Keywords: Ecosystem-based management, Marine pelagic community, Management objective, MSFD, CFP

\section{Introduction}

High-level strategic goals for marine ecosystems and fisheries are determined by international policy frameworks such as the European Common Fisheries Policy (CFP) and Marine Strategy Framework Directive for Europe (MSFD) [26]. The CFP is a set of regulations stating that fish stocks should be exploited below or at MSY (maximum sustainable yield) taking ecosystem considerations into account and ensuring that exploitation 
actions are precautionary, while the MSFD is an EU Environmental Directive, expected to be implemented for fisheries through the CFP as part of an 'Ecosystem Based Fisheries Management' (EBFM) framework. The MSFD groups broad ecosystem objectives into categories called descriptors, for which the objective is to reach 'Good Environmental Status' (GES). Ecosystem state in relation to management objectives (e.g., GES) is determined using indicators. In fisheries management under the MSFD and the CFP, indicators have two roles: providing (a) triggers for management measures ("control” function) and (b) evidence for management performance reporting ("audit" or "assessing” function) (Rice and Rivard, 2007). Indicators are thus considered essential for an ecosystem approach to monitoring and managing human pressures on marine ecosystems (De Young et al., 2008; Rice, 2011).

The hierarchy of high-level policy driven strategic goals, intermediate general ecological, economic and social objectives, and lower level operational objectives, needs to be defined before choosing suitable indicators (ICES, 2005; Jennings, 2005). In this study the hierarchical framework (Figure 1) was applied to Northeast Atlantic pelagic ecosystems. Pelagic communities have a pivotal role in the function of many large marine ecosystems, but have received much less attention in the scientific literature than demersal systems with respect to which general and which operational objectives might be relevant. However, specifying objectives for the pelagic is equally important for effective implementation of the MSFD.

\section{[Figure 1]}

\section{Methodology}

A stakeholder engagement process was undertaken to explore general ecological, economic and social management objectives for pelagic ecosystems (primarily for fish and top predators - birds and marine mammals). Examples of operational objectives, indicators and reference points were then identified for each stakeholder suggested objective based on a review of the scientific literature and expert knowledge (Figure 1). Operational objectives and reference points apply to specific stocks, marine (sub-) regions or fisheries, while most indicators are suitable for any pelagic ecosystem with the same operational objectives.

Involvement of 'stakeholders' is considered a crucial part of EBFM (Garcia and Cochrane, 2005). All parties gain from this relationship, which stems from stakeholders having a right to decide how the marine environment is used, and an associated responsibility for sustainable 
use (Gray and Hatchard, 2008). Operationally, this requires definition and representation of stakeholders. Here the stakeholder definition by Lorance et al. (2011) was used: public, private/business, associations/groups/NGOs and individual stakeholders. Public stakeholders include fisheries scientists and managers (national and European). Stakeholder involvement was implemented by inviting stakeholders with interest in pelagic fisheries to two separate workshops (the first involving scientists and the second other stakeholders) to explore and list ecological, economic and social management objectives that might be suitable for the management of Northeast Atlantic pelagic ecosystems. The workshops were both organized by scientists, but selection of objectives was independent and intended to give each group the freedom to identify objectives according to their own insights and priorities for pelagic fisheries and ecosystems.

An evidence-based approach was then applied to select indicators corresponding to proposed objectives. This approach consists of specifying operational objectives for a given general management objective based on published empirical evidence for a link between manageable pressures and relevant ecosystem states. Thus, a hypothesized pressure-state link based on theory was not taken as sufficient evidence.

The evidence-based approach interprets operational objectives at species and region scale and has not previously been applied to large pelagic systems. Ecological indicator developments have focused primarily on demersal communities (Caddy, 2004; Rochet and Trenkel, 2003; Rogers et al., 1999 etc), but see Trenkel et al. (2011), Trenkel and Berger (2013) and Shephard et al. (2014) for some pelagic examples. Pelagic fish species set distinct requirements for indicators, since they can exhibit substantial, environmentally influenced, fluctuations in abundance and wide-ranging mobility (Cury et al., 2003). For small, and medium sized, pelagic fish species, high variability on different scales is created by schooling behaviour, environmentally driven long distance (thousands of kilometers) migrations between spawning, feeding and nursery grounds, and strong recruitment fluctuations (King and McFarlane, 2003). "Small-pelagic" fish communities consist of few species, leading to the term wasp-waist food webs, though these waists are rather barrels if considered in terms of biomass (Fréon et al., 2009; Madigan et al., 2012). In contrast to many demersal mixedspecies fisheries, pelagic fishing generally targets single species (Checkley et al., 2009), so direct pelagic fishing impacts affect single stocks, though indirect effects may cause food web perturbations (Rochet et al., 2013). Further, pelagic fisheries do not damage vulnerable benthic habitats and the fisheries exhibit low $\mathrm{CO} 2$ footprints per kg of protein harvested 
94 (Parker and Tyedmers, 2014) and use little fuel energy per kJ of energy harvested (Trenkel et 95 al., 2013). The strong environmental forcing of recruitment, growth and survival makes for very uncertain biomass reference-points based on the single species stock assessments used in the management of pelagic fish stocks (Barange et al., 2009; Dickey-Collas et al., 2010). The challenge is increased by the need to broaden management objectives to implement an EBFM for pelagic fisheries under EU jurisdiction (Fu et al., 2012). Lastly, the primary anthropogenic impact on the marine ecosystem in Europe is fishing; fishing can drive shifts in pelagic fish communities (Ward and Myers, 2005).

\section{Exploring ecological, economic and social objectives}

The stakeholder workshops took place in spring 2013. For the scientist workshop, six participants in the EU-funded Myfish project (www.myfishproject.eu) were selected, based on their experience either in Northeast Atlantic pelagic fisheries, or EBFM. The scientists listed 22 potential objectives without seeking agreement on their relevance and defined a categorisation scheme grouping objectives related to societal values, food web structure and flow, fish population structure and flow, habitat quality and quantity, and fisheries yields (Table S1 in Supplementary Material). For each objective, responsiveness to fisheries management was considered.

For the second (other stakeholders) workshop, individuals with active involvement in advice, debate or implementation of either management for Northeast Atlantic pelagic stocks or EBFM were invited. The invitation was accepted by eight representatives from three stakeholder categories: NGO (1), fisheries managers (3), and pelagic fishing industry (4), facilitated by three scientists. As in the first workshop participants were asked to list management objectives they considered crucial for pelagic ecosystems and fisheries, and all suggestions were again accepted without challenge by the facilitators. The facilitators asked 'clarifying' questions to define distinct objectives, encouraging a wide range of ecological concepts in relation to GES to be considered, but did not disclose the list of objectives created in the first workshop. This lead to nineteen objectives being listed (Table S1). For each objective the likelihood that fisheries management could help to reach it was discussed.

The two workshops resulted in a total of 26 objectives being suggested (Table 1). There was rather good agreement between the scientists and the other stakeholders: 58\% (15) 
124

125

126

127

128

129

130

131

132

133

134

135

136

137

138

139

140

141

142

143

144

145

146

147

148

149

150

151

152

153

objectives were suggested in both (Table S1, Supplementary material). All 26 objectives were retained for the subsequent steps.

[table 1]

\section{Identifying operational management objectives and indicators}

For each of the 26 objectives, denoted $\mathrm{O} 1$ to O26, it was then attempted to identify examples of potential operational objectives for Northeast Atlantic pelagic stocks and ecosystems (Table 1). In each case the available scientific knowledge was considered and, if possible, examples were selected where fisheries management or management of other human activities can be expected to help move the pelagic ecosystem towards GES, i.e. cases with evidence for a pressure-state relationship. In the absence of such evidence no operational objectives were selected while for the identified cases suitable indicators, reference points and management actions were proposed (Table 1). Three criteria were used for selecting indicators: theoretical or empirical basis, measurement, and sensitivity, among the nine criteria proposed by Rice and Rochet (2005). In the following, the supporting evidence for the proposed operational objectives, indicators and reference points are provided. For conciseness and stressing the link with management, objectives were grouped by their ecological or management connection as shown in Figure 2 rather than the objective categorization scheme developed during the workshops.

[figure 2]

\subsection{Managing catch composition}

\subsubsection{Limit slippage and discarding (O1 \& O25)}

Discarding of target and non-target species is common practice in Northeast Atlantic pelagic fisheries, with discard proportions commonly varying between zero and $10 \%$ of total catch by weight (Berrow et al., 1998; Borges et al., 2008; Enever et al., 2007; McCarthy et al., 2011; Pierce et al., 2002; Tsagarakis et al., 2012). Slippage, which refers to the release of catch before hauling on board, and pumping back to sea from chilling tanks also occur (Borges et al., 2008; Pierce et al., 2002). Slippage has been found in 9\% of hauls, accounting for $\sim 10 \%$ of discards (Borges et al., 2008). McCarthy et al. (2011) found 11\% slippage, usually due to mixed species in the catch, or small fishes. Slippage rate and discard proportion are suitable indicators and based on the available knowledge, operational objectives for these 
154 for Northeast Atlantic pelagic fisheries (O1) and species (O25) can be set (see examples in

155 table 1). Limits to slippage and discarding may be set on ethical, economic, or ecological 156 grounds. There is no scientific basis for setting reference levels on ethical grounds and no

157

158

159

160

161

162

163

164

165

166

167

168

169

170

171

172

173

174

175

176

177

178

179

180

181

182

183

184

185 published study was found evaluating the economic consequences of discarding or slipping in pelagic fisheries. In the European context, the recent reform of the CFP includes a limitation of discard rates (Council of the European Union, 2013). Ecological impacts of discarding are widespread, ranging from increased mortality on target and non-target species to influencing the species composition of bird communities as several marine bird species feed on discards (Bicknell et al., 2013; Heath et al., 2014), and their spatial distribution (Bartumeus et al., 2010). Impacts on benthic scavenging communities have also been suggested (Kaiser and Hiddink, 2007). In summary, there are no clear scientific grounds for setting reference levels.

Management tools include changes in gear, spatio-temporal closures and development of markets for low value fish species, and of course, landing obligation and catch quotas instead of landing quotas. Allowing some flexibility in quota distribution across vessels could reduce discards caused by lack of quota.

\subsubsection{Limit bycatch of marine mammals, birds, and elasmobranchs (O2 \& O8)}

Bycatch of marine mammals in Northeast Atlantic pelagic trawl fisheries is generally between 0 to 0.07 individuals per haul (Berrow et al., 1998; Fernandez-Contreras et al., 2010; McCarthy et al., 2011; Morizur et al., 1999), but there are also higher rates (Morizur et al. 1999, Morizur et al. 2012). Dutch pelagic trawlers have been recorded as having bycatches of several dolphins and whale species (Couperus, 1997), though none have been reported in recent years (ICES 2013). McCarthy et al. (2011) also reported a small bycatch of seabirds, large pelagic species and sharks. For bluefin tuna fisheries, the bycatch of birds, sharks and marine mammals is a major issue (Anderson et al., 2011; Gilman, 2011). All pelagic fisheries in Europe with Marine Stewardship Council (MSC) accreditation now have to prove successful discard and bycatch reduction measures.

In the workshops, two different reasons to avoid bycatch emerged: limit bycatch numbers because killing even a low number of animals is ethically unacceptable or limit bycatch rates to ensure viable populations of bycatch species are maintained. In either case operational objectives for bycatch of marine mammals can be set with bycatch rate as indicator. In the second case this rate must reflect the sustainable mortality from bycatch of the population (Tuck, 2011). 
Management measures which might result in a reduction in bycatch rates include changes in gear characteristics (e.g. escape and deferment devices), modified gear deployment strategies, or spatio-temporal closures.

\subsection{Managing contaminants}

\subsubsection{Achieve low level of contaminants from land (O3) and limit recruitment impairment (O21)}

Concerns about contaminants are driven by perceived risks to human health and/or ecosystem functioning. For setting limit targets, it is assumed that whichever provides the lower threshold for the contaminant should be used as the reference limit.

A wide range of chemical contaminants have been reported in commercial fish species (Julshamn et al., 2004). There are large differences among Northeast Atlantic marine areas with herring from the Baltic Sea showing the highest contamination levels (Karl and Lahrssen-Wiederholt, 2013). The amount of contaminants in fish products is routinely measured to ensure that the European legislation for reference levels (EC, 2006) is adhered to, making contaminant concentrations feasible indicators of contaminant loads, which can be measured with reasonable accuracy and are readily available.

Contaminants can affect marine organisms, as can microplastic fragments (Oliveira et al., 2013). So instead of monitoring contaminant levels the complementary approach is to monitor biological effects using so called biological-effect techniques (Lyons et al., 2010; Thain et al., 2008), although the MSFD does not consider monitoring biological effects. These range from responses measured at the subcellular level to whole-organism responses such as growth impairment, disease occurrence or reduction of reproductive success. A list of candidate bivalves and fish species for biological-effect measurements has been suggested, together with reference levels (Thain et al., 2008), though pelagic fish species were not included. A recent empirical study could not find any evidence for a link between the presence of microplastic in fish stomachs and body condition (Foekema et al., 2013). Hence, as the evidence for a direct link between contaminants and pelagic fish recruitment is still sparse, no operational objectives or indicators were defined for O21. Further research is needed in this area. 


\subsection{Managing impacts on pelagic organisms}

\subsubsection{Maintain exploited stocks (O4)}

Maintaining exploited stocks has been a goal of fisheries management since it was realised that the resources of the sea are not infinite. In Europe and elsewhere, the biological indicators used for this are fishing mortality, biomass (or spawning stock biomass), or both (Quinn and Collie, 2005). Both have a number of reference points, including ones compatible with MSY (O24). When fishing is the major force acting on a stock, the two indicators respond rapidly to catch quota changes. For stocks where exploitation is a small proportion of total mortality, as is the case for many pelagic stocks, or the fish are long lived and slow growing, the response to management is often slow or lacking, e.g. sprat in the Skagerrak and Kattegat (ICES, 2013).

\subsubsection{Maintain food supply for higher trophic levels (O5) and their condition (O11 \& 015)}

Small pelagic species are an important prey for many higher trophic level predators, and generally only few species occupy this niche. However, this does not generally lead to strong dependence as many piscivorous fish predators are generalist feeders able to buffer variations in single prey abundances (Link and Garrison, 2002; Trenkel et al., 2005). This view is supported by Dickey-Collas et al. (2014) who classed the main predators of small pelagic fish species in the North Sea with respect to their vulnerability to abundance changes in their prey. Only in special circumstances can dependence of predators on certain preys become limiting, such as in ecosystem with few prey species or predators with a small prey portfolio and localised distribution. Baltic Sea cod feeding on sprat and herring seems to be such a case (Eero et al., 2012), there are indications that the pelagic prey of cod may have moved spatially further away (north) from the cod populations. Other documented examples include the dependence of certain seabirds on local abundance of sandeel in the North Sea (Rindorf et al., 2000; Wanless et al., 2005). Marine mammals may be less dependent because of broader dietary spectra and wider geographic distributions (Santos and Pierce, 2003; Trites et al., 1997).

Operational objectives for pelagic prey food availability (O5) could usefully be set for the biomass of herring and sprat in the area occupied by Baltic Sea cod and for North Sea sandeel in the distribution areas of dependent seabirds. Aggregate biomass over all pelagic fish 
species makes a suitable indictor for this objective. A potential reference point can be derived by summing stock level reference points.

The two suggested operational objectives for pelagic prey food availability are closely linked with the body condition of cod and the reproductive performance of seabirds, which in turn could be operational objectives for O11 and O15. Parsons et al. (2008) suggested as indicators the productivity (number of chicks fledged per nest) for seabirds, or the body condition for cod, but these indicators may respond to factors other than fishing, e.g. weather conditions or the abundance of alternative prey (Smout et al., 2013).

Thus, if the prey species are commercially exploited, their management needs to consider the demands of the wider ecosystem, inter alia by ensuring a sufficient escape rate, but also socio-economic implications for other fisheries (Dickey-Collas et al., 2014).

\subsubsection{Maintain functional (O6 \& O10) and structural (O7 \& O9) pelagic diversity}

Function and functioning have several meanings in ecology (Jax, 2005) and 'functional diversity' depends on the range of functions included (Petchey and Gaston, 2006). Here, the scope of ecosystem functions was restricted to energy and mass flow in the pelagic food web, excluding services such as gas-exchange and pollution breakdown since predator-prey interactions dominate the nektonic components of the pelagic ecosystem in the context of fisheries management (Pauly and Christensen, 1995). Functional diversity describes a range of roles: e.g. trophic levels, diets, predator identities, among any taxonomic or other organisational abstraction (see Lyashevska and Farnsworth, 2012). Reecht et al. (2013) formed functional groups of predators, using morphometric descriptors, whereas Rossberg et al. (2006) resolved morphometric/taxonomic groups into trophic descriptors.

For practical purposes, the objectives to "maintain functional diversity" (O6) and to "maintain a functional plankton community" (O10) can be interpreted as maintaining the viability of every functional group of a given pelagic ecosystem. For the relatively small number of cephalopod, fish, bird and mammal species that compose the higher trophic levels of pelagic ecosystems, this might be considered equivalent to maintaining the population viability of these species. This objective may best be achieved by the current stock-based management system using spawning stock biomass and fishing mortality as indicators. This has the advantage of incorporating theoretically robust reference points that are already tested. Dickey-Collas et al. (2014) argue that for forage fish, our current knowledge of their functions is insufficient to treat them as a single group. Somewhat pragmatically this view was extended 
278 to the whole pelagic ecosystem, but there is a need for the development of more function279 orientated food-web indicators, based on diet choice and the organism traits that give rise to it. 280 Ecological structure is defined as the identities, population sizes and nature of ecological interactions among components of the ecosystem (Noss, 1990). Thus species richness and evenness indicators are (partial) measures of structural diversity. Taking a functional perspective, ecosystem components may identify not species, but functional trait groups, such as body-size categories. Again, for pragmatic reasons, the current stock-based assessment and management system may be found most appropriate to address ecological structure (O7) and prey diversity (O9), simplifying the issue to one of maintaining natural long-term population sizes and age/size structures of existing populations.

None of the small and medium-sized pelagic fish species are currently considered endangered or vulnerable in Northeast Atlantic ecosystems (Bay of Biscay: Lorance et al. (2009), elsewhere: IUCN European fish evaluation pers. com (to be published in 2014)). In contrast, several large pelagic species give rise to concern. The IUCN has classed albacore (Thunnus alalunga) as 'near threatened', Atlantic bluefin tuna (Thunnus thynnus) as 'endangered', and basking shark (Cetorhinus maximus) and porbeagle (Lamna nasus) as 'vulnerable'. Apart from albacore and bluefin tuna, none of the other listed species have directed fisheries, the main fishery-induced mortality is through bycatch, which links these objectives to $\mathrm{O} 2$ and $\mathrm{O} 8$.

\subsubsection{Maintain stock component diversity (O12) and age structure (O13)}

Many of the large stocks of small pelagic fish species are made up of several components, which occupy spatially distinct areas at certain life stages. For example, North Sea herring consists of at least four different components with distinct spawning areas (Schmidt et al., 2009). For herring there is genetic distance across geographic space, but no clear distinct genetic isolation across the different spawning components (Mariani et al., 2005). Management measures to maintain stock component diversity (O12) could be area and season

304 based, and in particular should avoid serial depletion of the different components (Al305 Humaidhi et al., 2013).

The age structure (O13) of a stock might affect communal behaviour such as the choice of migration pathways through 'entrainment', with older experienced fish leading younger fish 308 in the migration (Petitgas, 2010); examples include capelin, herring, sardine and anchovy. A 309 potential indicator of this is abundance or proportion of fish that are older than age-at- 
310

311

312

313

314

315

316

317

318

319

320

321

322

323

324

325

326

327

328

329

330

331

332

333

334

335

336

337

338

339

340

maturity plus one year (Shephard et al., 2014), with as reference point some deviation from the long-term mean. Maintaining a population of older spawners also helps achieve objectives O14, O16 and by implication O17. Regulating the size/age selection pattern of fisheries (Brunel and Piet, 2013) may be monitored via the juvenile exploitation index: the ratio of fishing mortality on immature and mature individuals (Vasilakopoulos et al., 2012).

\subsubsection{Maintain genetic diversity (O16) and phenotypic width (O17)}

These objectives concern the ability of populations to respond to future stresses by maintaining a broad gene-pool to support a broad phenotype range. The main threats to the gene pool are non-selective, e.g. excessive fishing leading to a restricted gene pool, and selective, i.e. fishing or climate change directly selecting against certain genotypes. Restricted gene pools are avoided by maintaining healthy population sizes (Reiss et al., 2009). Theoretically fishing can select particular phenotypes or genotypes by altering differential survival in a mixed population, e.g. maturation size reaction norms, or migration rates (Heino and Hanski, 2001). It can also do so through targeting different spawning grounds (covered in relation to $\mathrm{O} 12$ above).

There is little convincing evidence for fishery induced evolution in pelagic fish. Engelhard and Heino (2004) demonstrated substantial changes in growth and maturation, but considered that this was mainly phenotypic, and at most a weak evolutionary response. However, this does indicate a considerable range of phenotypic plasticity. Similarly, no evidence of climate change induced genetic selection was found by Heath et al. (2012). Therefore, determining operational objectives, other than preventing overly selective fishing (O16), is difficult, as is selecting suitable indicators.

\subsection{Managing impacts on habitats}

\subsubsection{Maintain spatial distribution of pelagic fish (014)}

Changes in spatial distribution and migration and the possible cause of this were reviewed for a wide range of Northeast Atlantic pelagic species in Petitgas (2010) and Trenkel et al. (2014). Many biotic and abiotic factors across different life stages regulate distributions and it is often difficult to isolate the underlying causes with fishing, local productivity, environmental conditions, spreading of neighbouring big stocks and predator-prey interactions all combining to cause variation in spatial distributions. For example, the appearance and disappearance of anchovy in the North Sea, the Kattegat and Skagerrak has 
341 been viewed as a northern migration or extension of the southern population (Alheit et al.,

342 2012) but others now suggest that it is a local population which has become more productive over time (Petitgas et al., 2012; Raab et al., 2013). Neither of these explanations directly involves a mechanism resulting from human activity. Thus, as the factors impacting spatial distributions of pelagic fish are poorly understood, no operational objectives and indicators were proposed.

\subsubsection{Maintain spawning habitat (O18)}

Most small and medium-sized pelagic fish species are water column spawners, often along the continental shelf edge, notable exceptions being herring and capelin who deposit their eggs on gravel in shallow waters with strong currents (reviewed in Trenkel et al., 2014). For water column spawners, environmental conditions such as temperature and salinity influence the geographic position of spawning habitats, and so management to "maintain" these would be challenging. For herring and capelin gravel extraction or construction on sites might modify suitable spawning habitat and suffocate eggs. Hence operational objectives were selected for herring and capelin only with as indicator the surface area of suitable habitat; reference values have to be case specific.

\subsubsection{Maintain juvenile (O19) and feeding (O20) habitats}

Most small and medium-sized pelagic fish species have distinct nursery grounds, and many are associated with shallow water at this life stage. For example herring stocks in the Northeast Atlantic tend to have inshore nursery areas (Geffen et al., 2001). Any strong link to a particular location would tend to increase risk, particularly when the nursery habitats occur in areas of high fishing or other anthropogenic pressures. Conversely, as species like mackerel, horse mackerel, anchovy and blue whiting juveniles are found extensively across the continental shelf, the main threat is being bycaught in bottom trawls. Again, defining operational objectives for juvenile or feeding habitats is difficult, not least because there are no documented cases where habitat degradation has impacted stock dynamics.

\subsubsection{Maintain migration pathways (O22)}

Where migration ways are highly conserved and specific, it should be ensured that physical constructions, such as dams, do not limit recruitment, as has been the case for herring in the North Sea when a dam was built to close off the Zuiderzee (Redeke, 1939). With Marine 
371 Spatial Planning (MSP) an operational objective can be set to avoid the obstruction of

372 migration-ways, using the percentage of migration ways impacted as an indicator.

\section{$373 \quad 4.5 \quad$ Managing impacts on fisheries}

374

375

376

377

378

379

380

381

\subsubsection{Optimal $(\mathrm{O} 23)$ and maximum sustainable $(\mathrm{O} 23)$ yield}

Optimal fisheries (O23) depend on healthy stocks (O4) and maximised sustainable yield (O24), in addition to accounting for economic, social and other considerations such as the interannual variability of landings. For example, the UK herring market never recovered after the collapse of North Sea herring (Dickey-Collas et al., 2010). For fishers themselves however, interannual variations in economic returns might be compensated between species (Trenkel et al., 2013). Relative interannual stability of landings is a suitable operational objective for pelagic fisheries, with interannual variation in landings as indicator. Suitable management measures are a constant TAC or a cap on its interannual change.

\subsubsection{Unobstructed fisheries (O26)}

Offshore wind farms are often perceived as limiting access to traditional fishing grounds, thus reducing the space to fish (O26), but there are no documented cases where this has actually happened for pelagic species. If needed, an operational objective could be to maintain physical space for fishing, with the indicator (reference point) being the size of suitable (minimum) fishing area. Management would be through MSP and co-location of activities (Christie et al., 2013).

\section{Discussion}

Selection of state indicators for marine ecosystems has often been based on data availability and ease of quantification. In this study stakeholder engagement was used to ensure a more credible and legitimate approach to define a set of general and operational management objectives and associated indicators for pelagic ecosystems. General objectives were developed through a participatory process ensuring social license to manage human activities. An evidence based-approach was then applied to identify operational objectives and the indicators needed for verifying that these objectives are met, and if not, be able to propose appropriate management responses. 
Stakeholder participation resulted in a heterogeneous set of pelagic management

400

401

402

403

404

405

406

407

408

409

410

411

412

413

414

415

416

417

418

419

420

421

422

423

424

425

426

427

428

429

430 objectives, including some which do not correspond to fisheries management, but may profoundly affect the ecosystem (e.g. pollutant contamination); some for which there is currently a lack of sufficient knowledge (e.g. obstruction of natural migration-ways and its impact); and some familiar fish stock-based objectives (Table 1). The majority of identified objectives were considered responsive to anthropogenic impacts in some form, with fisheries being the most frequent (20 out of 26 general pelagic objectives) (Table S1). The operational objectives proposed for each general objective provide relevant examples, rather than an exhaustive list for Northeast Atlantic pelagic ecosystems. Corresponding indicators were selected based on documented (or suspected) direct links with manageable pressures (equivalent to requiring a theoretical or empirical basis) and their sensitivity to management; measurability was a secondary criterion. Rice and Rochet (2005) list other indicator selection criteria which were not used in this study such as cost, public awareness or historical data, but these are clearly relevant for practical implementation.

In the following the 26 pelagic management objectives are discussed in terms of implications for management in the light of the experience gained in this study. Specificity to pelagic systems is also considered.

\subsection{Objectives related to societal values}

The three objectives related to societal value (O1-O3) might be considered the most normative, but they also include ecological effects: slippage involves mortality, but provides a food resource for scavengers and bycatch alters ecological structure and possibly stability (O'Gorman et al., 2011), while pollution can also affect marine organisms not only human health. The ethically perceived ideal level for all these is zero, the optimal operational level being found at some, as yet undetermined, economic equilibrium between the benefits of reducing these ills and the costs in doing so. Fisheries science can define total removal reference levels and sustainable bycatch rates of vulnerable or endangered species from life history and resilience traits. Science guidance is more difficult for contaminants from land as their impact on ecological functioning of pelagic ecosystems is not well understood.

\subsection{Objectives related to food web structure and flow}

For objectives related to 'normal' structure and flow of the food webs (O4-O11) the proposed operational objectives and indicators are specific to (particular) pelagic ecosystems, and operate mostly at the population level, even for the community indicators. This is 
431 because, unlike the demersal case, pelagic fish communities are composed of relatively few

432 species (except with plankton which was not considered here). This gives the systems a 433 potentially low functional redundancy and means it is both necessary and possible, in 434 practical terms, to manage on a species-by-species basis. Almost all exploited pelagic stocks 435 in Europe are already managed through population-level indicators (Barange et al. (2009), 436 Table S2, Supplementary material). The importance of single stock management in the wider 437 context of EBFM has long been recognized (Mace, 2004); it is particularly relevant for 438 pelagic ecosystems as illustrated by Shephard et al. (2014). This means that for maintaining 439 pelagic ecosystem functioning, GES of populations needs to be achieved to achieve GES at the community level. Acknowledging the pivotal role of the population level means that reference points are usually already available and population processes are rather well understood. An important caution here is that pelagic populations can show large natural variability and environmental conditions drive population dynamics. In many cases these will be beyond fisheries management and it is important to remember that these fluctuations in productivity are a natural systemic feature. Care should be taken, as many food web interactions are influenced by local dynamics and many fisheries management targets (such as MSY) are assessed and managed at much larger (sub-) regional scales. For example, foraging success of colony-based sea birds may depend on local populations of pelagic fish, whereas management of fisheries may be sea-wide. In summary, an important contrast with management towards GES for demersal fish communities is that the focus is on population indicators as indicators of the wider functioning of the pelagic food web.

\subsection{Objectives related to fish population structure and flow}

The objectives related to 'normal' structure and flow within fish populations (O12-O17) are principally about maintaining populations of pelagic fish in a healthy state, including phylo-geographic structure, age and size-structure, reproductive rate and body-condition, all of which contribute to the resilience of the pelagic system. Spatio-temporal management is needed to maintain component (phylo-geographic) diversity, though it could lead to fisheries that increasingly take fish from genetically mixed aggregates, thereby blurring the assessment of individual components (Hintzen et al., In Press). Healthy age structure and appropriate indicators and thresholds can be defined, but in practice, the operational objective may follow from direct management of the fisheries age/size selection (Brunel and Piet, 2013). Though the potential to manage growth and age of maturation is very limited, it can be monitored 
463

464

465

466

467

468

469

470

471

472

473

474

475

476

477

478

479

480

481

482

483

484

485

486

487

488

489

490

491

492

493

494

effectively during scientific surveys, but impacts of fishing on genetic or phenotypic diversity are difficult to determine, and to define within an indicator framework. In summary, for objectives related to pelagic populations there are obvious parallels with demersal ecosystems, including stock components, age structures and genetic and phenotypic diversity. The main differences lie in the inability to use spatial occupation as an indicator, and the poor evidence for fishing impacts on genetic diversity, and the wide phenotypic plasticity shown by many pelagic fish species (Engelhard and Heino, 2004).

\subsection{Objectives related to habitat quantity and quality}

Among the five objectives related to habitat quality and life cycle closure (O18-O22) operational objectives and indicators could only be defined for two. Pelagic ecosystems are characteristically open and connected over large areas and include substantial migrations among several species. The habitats are so wide in geographical scale and ill-defined in boundary, that spatial management and "protection" of habitats is difficult to justify. There are a few exceptions, mainly where habitats are highly specific (e.g. herring spawning on gravel, capelin spawning or sandeel burying in sand). The wide spatial range combined with highly aggregated local distribution of most pelagic fish has an additional consequence for fisheries and ecosystem management. Fishing effort control is unlikely to be an efficient management measure for stocks with density dependent distributions, as fishing catchability increases when the decreasing stocks contract in space (Beverton, 1990; Hamre, 1978; MacCall, 1990) and non-nested large spatial distributions covering all or parts of multiple marine sub-regions in the MSFD provide a challenge for regional management. In summary, this is the category of ecosystem objectives where pelagic ecosystems are most different from demersal ecosystems. Pelagic organisms can be seen as generally having substantial variation in spatio-temporal distribution, much greater than most demersal species. Unfortunately, there is little value in using spatial measures to protect specific habitats in other than the restricted number of cases of benthic spawners.

\subsection{Objectives related to fishery yields}

The objectives related to fisheries yield (O23-O26) included well known suggestions such as to keep stocks healthy and capable of producing a maximum and stable yield as well as other aspects related to variability in yield. European fisheries management deals primarily with yield and variability, generally through so called long term management plans. Though demersal fisheries have similar demands for stability of the resource, this objective is often 
495

496

497

498

499

500

501

502

503

504

505

506

507

508

509

510

511

512

513

514

515

516

517

518

519

520

521

522

523

524

525

526

automatically fulfilled for long lived stocks fished at moderate rates. While this is also true of comparatively long lived small pelagics such as herring and mackerel, this does not hold for short lived pelagics e.g. anchovy, capelin, sprat and sand eel, which are fished in what is essentially a recruitment fishery on stocks with limited and poorly understood relationships between stock size and recruitment. The characteristic "boom and bust" pattern seen in many small pelagic fisheries in Europe and worldwide, makes determining appropriate fishing pressures difficult in the context of MSY. As with objectives related to habitats, this is a key area where establishing GES, and indeed what is "healthy" for pelagic stocks is not only different from most demersal stocks, but may actually require a different approach: sensitive to the biology and life history characteristics of the species concerned. Additionally, the pelagic fisheries tend to target one, or two species at a time, whereas most Northeast Atlantic, but also Mediterranean demersal fisheries could be considered "mixed fisheries" that target two or three species and collect a suite of bycatch species, all with commercial value (e.g., Daurès et al., 2009). This leads to the description of pelagic fisheries as "clean” compared to demersal fisheries, further supporting the proposal to build community-level indicators from the population-level.

\subsection{Conclusions}

In this study a group of stakeholders developed a list of general pelagic GES ecosystem objectives. From these, example operational objectives and matching indicators were identified for Northeast Atlantic pelagic ecosystems. When translating the general management objectives into operational objectives, many were closely linked, in particular via a common management measure (Table 1, Figure 2). Others are linked logically, in the sense that meeting one objective should meet others, i.e. when meeting community level objectives depends on meeting population level objectives. A similar argument implies a spatial hierarchy (from sub-regions to whole systems) of assessments and management responses. Selected indicators often related to the management of fisheries on single stocks, facilitating their implementation, given present practice. It was argued that the relatively small number of fish species present in temperate pelagic ecosystems should allow their use as proxies for wider pelagic community concerns. The greatest gaps identified in our knowledge were those related to the factors regulating pelagic stocks: e.g. what are the roles of old fish, migration pathways or environmental factors? Without understanding causal links, or at least having empirical evidence, theoretically (empirically) based indicators for use in management 
cannot be suggested (Dickey-Collas et al., 2014). Managing pelagic stocks with respect to MSY is unlikely to be sufficient to provide the maximum social benefit of the fisheries. It is also likely to challenge achieving GES when local factors are active, such as forage requirements for nesting seabirds, or the bycatch from local populations of cetaceans. The tradeoff between maximizing yield and maintaining stability of catches remains unsolved, especially for pelagic species which are inherently highly variable. The high spatio-temporal variability, within a large-scale system (e.g. incorporating migrations) and the role of pelagic fish as intermediate predators and prey, indicates that management for GES probably requires a more integrated approach than currently envisaged in the MSFD and possibly elsewhere. Finally, the evidence-based pressure-state link approach used in this study is suitable beyond pelagic ecosystems for selecting operational objectives and indicators that can fruitfully inform management.

\section{Acknowledgements}

This work received funding from the European Union Seventh Framework Programme projects EURO-BASIN (ENV.2010.2.2.1-1) under grant agreement $n^{\circ} 264933$ and MYFISH (FP7/2007-2013) under grant agreement $n^{\circ}$ 289257. We thank an anonymous referee for comments which helped to improve the manuscript.

\section{References}

Al-Humaidhi, A.W., Wilson, J.A., Young, T.H., 2013. The local management of migratory stocks: Implications for sustainable fisheries management. Fish. Res., 141, 13-23.

Alheit, J., Pohlmann, T., Casini, M., Greve, W., Hinrichs, R., Mathis, M., O'Driscoll, K., Vorberg, R., Wagner, C., 2012. Climate variability drives anchovies and sardines into the North and Baltic Seas. Prog. Oceano., 96, 128-139.

Anderson, O.R.J., Small, C.J., Croxall, J.P., Dunn, E.K., Sullivan, B.J., Yates, O., Black, A., 2011. Global seabird bycatch in longline fisheries. Endangered Species Research, 14, 91-106.

Barange, M., Bernal, M., Cergole, M.C., Cubillos, L.A., Daskalov, G.M., de Moor, C.L., De Oliveira, J.A.A., Dickey-Collas, M., Gaughan, D.J., Hill, K., Jacobson, L.D., Köster, F.W., Massé, J., Ñiquen, M., Nishida, H., Oozeki, Y., Palomera, I., Saccardo, S.A., Santojanni, A., Serra, R., Somarakis, S., Stratoudakis, Y., Uriarte, A., van der Lingen, 
C.D., Yatsu, A., 2009. Current trends in the assessement and management of stocks, in: Checkley, D., Alheit, J., Oozeki, Y., Roy, C. (Eds.), Climate change and small pelagic fish. Cambridge University Press, Cambridge, pp. 191-255.

Bartumeus, F., Giuggioli, L., Louzao, M., Bretagnolle, V., Oro, D., Levin, S.A., 2010. Fishery discards impact on seabird movement patterns at regional scales. Curr. Biol., 20, 215222.

Berrow, S.D., O’Neill, M., Brogan, D., 1998. Discarding practices and marine mammal bycatch in the Celtic Sea herring fishery. P. Roy. Irish Acad., 98B, 1-8.

Beverton, R.J.H., 1990. Small marine pelagic fish and the threat of fishing: are they endangered? J. Fish Biol., 37 (Supplement A), 5-16.

Bicknell, A.W.J., Oro, D., Camphuysen, K., Votier, S.C., 2013. Potential consequences of discard reform for seabird communities. J. Appl. Ecol., 50, 649-658.

Borges, L., van Keeken, O.A., van Helmond, A.T.M., Couperus, B., Dickey-Collas, M., 2008. What do pelagic freezer-trawlers discard? ICES J. Mar. Sci., 65, 605-611.

Brunel, T., Piet, G.J., 2013. Is age structure a relevant criterion for the health of fish stocks? ICES J. Mar. Sci., 70, 270-283.

Caddy, J.F., 2004. Current usage of fisheries indicators and reference points, and their potential application to management of fisheries for marine invertebrates. Can. J. Fish. Aquat. Sci., 61, 1307-1324.

Checkley, D., Roy, C., Oozeki, Y., Alheit, J., 2009. Climate change and small pelagic fish stocks. Cambridge University Press.

Christie, N., Smyth, K., Barnes, R., Elliott, M., 2013. Co-location of activities and designations: A means of solving or creating problems in marine spatial planning? Mar. Policy, 43, 254-261.

Council of the European Union, 2013. Proposal for a regulation of the European parliament and of the council on the common fisheries policy.

Couperus, A.S., 1997. Interactions between Dutch midwater trawl and Atlantic white-sided dolphins (Lagenorhynchus acutus) Southwest of Ireland. J. Northw. Atl. Fish. Sci., 22, 209-218.

Cury, P., Shannon, L.J., Shin, Y.-J., 2003. The functioning of marine ecosystems: a fisheries perspective, in: Sinclair, M., Valdimarsson, G. (Eds.), Responsible fisheries in the marine ecosystem. CAB International, Wallingford, pp. 103-123. 
Daurès, F., Rochet, M.-J., Van Iseghem, S., Trenkel, V. M., 2009. Fishing fleet typology, economic dependence, and species landing profiles of the French fleets in the Bay of Biscay, 2000-2006. Aquat. Living Res., 22, 535-547.

De Young, C., Charles, A., Hjort, A., 2008. Human Dimensions of the Ecosystem Approach to Fisheries: An Overview of Context, Concepts, Tools and Methods, Fisheries Tech. Paper. FAO, Rome, p. 165.

Dickey-Collas, M., Engelhard, G.H., Rindorf, A., Raab, K., Smout, S., Aarts, G., van Deurs, M., Brunel, T., Hoff, A., Lauerburg, R.A.M., Garthe, S., Haste Andersen, K., Scott, F., van Kooten, T., Beare, D., Peck, M.A., 2014. Ecosystem-based management objectives for the North Sea: riding the forage fish rollercoaster. ICES J. Mar. Sci., 71, 128-142.

Dickey-Collas, M., Nash, R.D.M., Brunel, T., van Damme, C.J.G., Marshall, C.T., Payne, M.R., Corten, A., Geffen, A.J., Peck, M.A., Hatfield, E.M.C., Hintzen, N.T., Enberg, K., Kell, L.T., Simmonds, E.J., 2010. Lessons learned from stock collapse and recovery of North Sea herring: a review. ICES J. Mar. Sci., 67, 1875-1886.

Dickey-Collas, M., Payne, M.R., Trenkel, V.M., Nash, R.D.M., 2014. Hazard Warning: model misuse ahead. ICES J Mar. Sci., 71, 2300-2306.

EC, 2006. Commission regulation (EC) No 1881/2006 of 19 December 2006 setting maximum levels for certain contaminants in foodstuffs. Official Journal of the European Union, L 364, 5-23.

Eero, M., Vinther, M., Haslob, H., Huwer, B., Casini, M., Storr-Paulsen, M., Köster, F.W., 2012. Spatial management of marine resources can enhance the recovery of predators and avoid local depletion of forage fish. Conser. Lett., 5, 486-492.

Enever, R., Revill, A., Grant, A., 2007. Discarding in the English Channel, Western approaches, Celtic and Irish seas (ICES subarea VII). Fish. Res., 86, 143-152.

Engelhard, G.H., Heino, M., 2004. Maturity changes in Norwegian spring-spawning herring Clupea harengus: compensatory or evolutionary responses? Mar. Ecol. Prog. Ser., 272, 245-256.

European Union, 2008. Directive 2008/56/EC of the European Parliament and of the Council of 17 June 2008 establishing a framework for community action in the field of marine environment policy (Marine Stategy Framework Directive). Official Journal of the European Union 25.6.2008 L164, 19-40. 
621 Fernandez-Contreras, M.M., Cardona, L., Lockyer, C.H., Aguilar, A., 2010. Incidental

622

623

624

625

626

627

628

629

630

631

632

633

634

635

636

637

638

639

640

641

642

643

644

645

646

647

648

649

650

651

652

653 bycatch of short-beaked common dolphins (Delphinus delphis) by pairtrawlers off northwestern Spain. ICES J. Mar. Sci., 67, 1732-1738.

Foekema, E.M., De Gruijter, C., Mergia, M.T., van Franeker, J.A., Murk, A.J., Koelmans, A.A., 2013. Plastic in North Sea fish. Environmental Science \& Technology, 47, 8818-8824.

Fréon, P., Arístgui, J., Bertrand, A., Crawford, R.J.M., Field, J.C., Gibbons, M.J., Tam, J., Hutchings, L., Masski, H., Mullon, C., Ramdani, M., Seret, B., Simier, M., 2009. Functional group biodiversity in Eastern Boundary Upwelling Ecosystems questions the wasp-waist trophic structure. Prog. Oceanogr., 83, 97-106.

Fu, C., Gaichas, S.K., Link, J.S., Bundy, A., Boldt, J.L., Cook, A.M., Gabmle, R., Rong Utne, K., Liu, H., Friedland, K.D., 2012. Relative importance of fisheries, trophodynamics and environmental drivers in a series of marine ecosystems. Mar. Ecol. Prog. Ser., 459, 169-184.

Garcia, S.M., Cochrane, K.L., 2005. Ecosystem approach to fisheries: a review of implementation guidelines. ICES J. Mar. Sci., 62, 311-318.

Geffen, A.J., Nash, R.D.M., Dickey-Collas, M., 2001. Characterisation of herring populations to the west of the British Isles: an investigation of mixing between populations based on otolith microchemistry. ICES J. Mar. Sci., 68, 1447-1458.

Gilman, E.L., 2011. Bycatch governance and best practice mitigation technology in global tuna fisheries. Mar. Policy, 35, 590-609.

Gray, T., Hatchard, J., 2008. A complicated relationship: Stakeholder participation and the ecosystem-based approach to fisheries management. Mar. Policy, 32, 158-168.

Hamre, J., 1978. The effect of recent changes in the North Sea mackerel fishery on stock and yield. Rapp. P.-v. Réun. Cons. Int. Explor. Mer, 172, 197-210.

Heath, M.R., Cook, R.M., Cameron, A.I., Morris, D.J., Speirs, D.C., 2014. Cascading ecological effects of eliminating fishery discards. Nature Communications, 5, doi:10.1038/ncomms4893.

Heath, M.R., Neat, F.C., Pinnegar, J.K., Reid, D.G., Sims, D.W., Wright, P.J., 2012. Review of climate change impacts on marine fish and shellfish around the UK and Ireland. Aquat. Conserv., 22, 337-367.

Heino, M., Hanski, I., 2001. Evolution of migration rate in a spatially realistic metapopulation model. American Naturalist, 157, 495-511. 
654 Hintzen, N.T., Roel, B., Benden, D., Clarke, M., Egan, A., Nash, R.D.M., Rohlf, N., Hatfield,

655

656

657

658

659

660

661

662

663

664

665

666

667

668

669

670

671

672

673

674

675

676

677

678

679

680

681

682

683

684

685

686 E.M.C., In Press. Managing a complex population structure: exploring the importance of information from fisheries independent sources. ICES J. Mar. Sci. doi: 10.1093/icesjms/fsu102.

ICES, 2005. Guidance on the application of the ecosystem approach to management of human activities in the European marine environment, ICES Co-operative Research Report, pp. http://www.ices.dk/sites/pub/Publication\%20Reports/Cooperative\%20Research\%20Re port\%20(CRR)/crr273/crr273.pdf.

ICES, 2013. Report of the herring assessment working group for the area South of $62 \mathrm{~N}$ (HAWG). 2013/ACOM:06, 1283

pp, http://www.ices.dk/sites/pub/Publication\%20Reports/Expert\%20Group\%20Report/aco m/2013/HAWG/HAWG\%202013.pdf

Jax, K., 2005. Function and "functioning" in ecology: what does it mean? Oikos, 111, 641648.

Jennings, S., 2005. Indicators to support an ecosystem approach to fisheries. Fish Fish., 6, 212-232.

Julshamn, K., Lundebye, A.K., Heggstad, K., Berntssen, M.H.G., Boe, B., 2004. Norwegian monitoring programme on the inorganic and organic contaminants in fish caught in the Barents Sea, Norwegian Sea and North Sea, 1994-2001. Food Addit. Contam., 21, 365-376.

Kaiser, M.J., Hiddink, J.G., 2007. Food subsidies from fisheries to continental shelf benthic scavengers. Mar. Ecol. Prog. Ser., 350, 267-276.

Karl, H., Lahrssen-Wiederholt, M., 2013. Factors influencing the intake of dioxins and dioxin-like PCBs via fish consumption in Germany. Journal of Consumer Protection and Food Safety, 8, 27-35.

King, J.R., McFarlane, G.A., 2003. Marine fish life history strategies: applications to fishery management. Fish. Manag. Ecol., 10, 249-264.

Link, J.S., Garrison, L.P., 2002. Trophic ecology of Atlantic cod Gadus morhua on the northeast US continental shelf. Mar. Ecol. Prog. Ser., 227, 109-123.

Lorance, P., Agnarsson, S., Damalas, D., des Clers, S., Figueiredo, I., Gil, J., Trenkel, V.M., 2011. Using qualitative and quantitative stakeholder knowledge: examples from European deep-water fisheries. ICES J. Mar. Sci., 68, 1815-1824. 
687

688

689

690

691

692

693

694

695

696

697

698

699

700

701

702

703

704

705

706

707

708

709

710

711

712

713

714

715

716

717

Lorance, P., Bertrand, J.A., Brind'Amour, A., Rochet, M.-J., Trenkel, V.M., 2009. Assessment of impacts from human activities on ecosystem components in the Bay of Biscay in the early 1990s. Aquat. Living Resourc., 22, 409-431.

Lyashevska, O., Farnsworth, K.D., 2012. How many dimensions of biodiversity do we need? Ecol. Ind., 18, 485-492.

Lyons, B.P., Thain, J.E., Stentiford, G.D., Hylland, K., Davies, I.M., Vethaak, A.D., 2010. Using biological effects tools to define Good Environmental Status under the European Union Marine Strategy Framework Directive. Mar. Poll. Bull., 60, 16471651.

MacCall, A.D., 1990. Dynamic geography of marine fish populations. University of Washington Press, Seattle, W.A., 153 pp.

Mace, P.M., 2004. In defence of fisheries scientists, singe-species models and other scapegoats: confronting the real problems. Mar. Ecol. Prog. Ser., 274, 285-291.

Madigan, D.J., Carlisle, A.B., Dewar, H., Snodgrass, O.E., Litvin, S.Y., Micheli, F., Block, B.A., 2012. Stable isotope analysis challenges wasp-waist food web assumptions in an upwelling pelagic ecosystem. Nature Scientific Reports, 2, 6-54.

Mariani, S., Hutchinson, W.F., Hatfield, E.M.C., Ruzzante, D.E., Simmonds, E.J., Dahlgren, T.G., Andre, C., Brigham, J., Torstensen, E., Carvalho, G.R., 2005. North Sea herring population structure revealed by microsatellite analysis. Mar. Ecol. Prog. Ser., 303, 245-257.

McCarthy, A., Pinfield, R., Enright, J., Rogan, E., 2011. Pilot observer programme in Irish pelagic trawl and gillnet fisheries: Implementing Council Regulation (EC) No $812 / 2004$.

Morizur, Y., Berrow, S.D., Tregenza, N.J.C., Couperus, A.S., Pouvreau, S., 1999. Incidental catches of marine-mammals in pelagic trawl fisheries of the northeast Atlantic. Fish. Res., 41, 297-307.

Noss, R.F., 1990. Indicators for monitoring biodiversity - a hierarchical approach. Conserv. Biol., 4, 355-364.

O'Gorman, E.J., Yearsley, J.M., Crowe, T.P., Emmerson, M.C., Jacob, U., Petchey, O.L., 2011. Loss of functionally unique species may gradually undermine ecosystems. Proc. R. Soc. B-Biol. Sci., 278, 1886-1893. 
Oliveira, M., Ribeiro, A., Hylland, K., Guilhermino, L., 2013. Single and combined effects of microplastics and pyrene on juveniles ( $0+$ group) of the common goby Pomatoschistus microps (Teleostei, Gobiidae). Ecol. Ind., 34, 641-647.

Parker, R.W.R., Tyedmers P.H., 2014. Fuel consumption of global fishing fleets: current understanding and knowledge gaps. Fish Fish., DOI: 10.1111/faf.12087.

Parsons, M., Mitchell, I., Butler, A., Ratcliffe, N., Frederiksen, M., Foster, S., Reid, J.B., 2008. Seabirds as indicators of the marine environment. ICES J. Mar. Sci., 65, 15201526.

Pauly, D., Christensen, V., 1995. Primary production required to sustain global fisheries. Nature, 374, 255-257.

Petchey, O.L., Gaston, K.J., 2006. Functional diversity: back to basics and looking forward. Ecol. Letters, 9, 741-758.

Petitgas, P., (Eds) 2010. Life-cycle spatial patterns of small pelagic fish in the Northeast Atlantic. ICES Cooperative Reserach Report 306, p. 94.

Petitgas, P., Alheit, J., Peck, M.A., Raab, K., Irigoien, X., Huret, M., van der Kooij, J., Pohlmann, T., Wagner, C., Zarraonaindia, I., Dickey-Collas, M., 2012. Anchovy population expansion in the North Sea. Mar. Ecol. Prog. Ser., 444, 1-13.

Petitgas, P., Rijnsdorp, A.D., Dickey-Collas, M., Engelhard, G.H., Peck, M.A., Pinnegar, J.K., Drinkwater, K., Huret, M., Nash, R.D.M., 2013. Impacts of climate change on the complex life cycles of fish. Fish. Oceanog., 22, 121-139.

Pierce, G.J., Dyson, J., Kelly, E., Eggleton, J.D., Whomersley, P., Young, I.A.G., Santos, M.B., Wang, J.J., Spencer, N.J., 2002. Results of a short study on by-catches and discards in pelagic fisheries in Scotland (UK). Aquat. Liv. Resourc., 15, 327-334.

Quinn, T.J., Collie, J.S., 2005. Sustainability in single-species populations models. Philosophical Transactions of the Royal Society London Series B, 360, 147-162.

Raab, K., Llope, M., Nagelkerke, L.A.J., Rijnsdorp, A.D., Teal, L.R., Licandro, P., Ruardij, P., Dickey-Collas, M., 2013. Influence of temperature and food availability on juvenile European anchovy Engraulis encrasicolus at its northern boundary. Mar. Ecol. Prog. Ser., 488, 233-245.

Redeke, H.C., 1939. The effect of the closure of the Zuiderzee on fish and fisheries. J. Cons. int. Explor. Mer, 14, 337-346. 
Reiss, H., Hoarau, G., Dickey-Collas, M., Wolff, W.G., 2009. Genetic population structure of marine fish: mismatch between biological and fisheries management units. Fish Fish., 10, 361-395.

Rice, J.C., 2011. Managing fisheries well: delivering the promises of an ecosystem approach. Fish Fish., 12, 209-231.

Rice, J.C., Rivard, D., 2007. The dual role of indicators in optimal fisheries management strategies. ICES J. Mar. Sci., 64, 775-778.

Rice, J.C., Rochet, M.-J., 2005. A framework for selecting a suite of indicators for fisheries management. ICES J. Mar. Sci., 62, 516-527.

Rindorf, A., Wanless, S., Harris, M.P., 2000. Effects of changes in sandeel availability on the reproductive output of seabirds. Mar. Ecol. Prog. Ser., 202, 241-252.

Rochet, M.J., Collie, J.S., Trenkel, V.M., 2013. How do fishing and environmental effects propagate among and within functional groups? Bull. Mar. Sci., 89, 285-315.

Rochet, M.J., Trenkel, V.M., 2003. Which community indicators can measure the impact of fishing ? A review and proposals. Can. J. Fish. Aquat. Sci., 60, 86-99.

Rogers, S.I., Maxwell, D., Rijnsdorp, A.D., Damm, U., Vanhee, W., 1999. Fishing effects in northeast Atlantic shelf seas: patterns in fishing effort, diversity and community structure. IV. Can comparisons of species diversity be used to assess human impacts on demersal fish faunas ? Fish. Res., 40, 135-152.

Rossberg, A.G., Matsuda, H., Amemiya, T., Itoh, K., 2006. Food webs: Experts consuming families of experts. J. Theoretical Biology, 241, 552-563.

Santos, M.B., Pierce, G.J., 2003. The diet of harbour porpoise (Phocoena phocoena) in the northeast Atlantic, in: Gibson, R.N., Atkinson, R.J.A. (Eds.), Oceanography and Marine Biology, Vol 41, pp. 355-390.

Schmidt, J.O., van Damme, C.J.G., Röckmann, C., Dickey-Collas, M., 2009. Recolonisation of spawning grounds in a recovering fish stock: recent changes in North Sea herring. Scientia Marina, 73S1, 153-157.

Shephard, S., Rindorf, A., Dickey-Collas, M., Hintzen, N.T., Farnsworth, K., Reid, D.G., 2014. Assessing the state of pelagic fish communities within an ecosystem approach and the European marine strategy framework directive. ICES J. Mar. Sci., 71, 15721585.

Smout, S., Rindorf, A., Wanless, S., Daunt, F., Harris, M.P., Matthiopoulos, J., 2013. Seabirds maintain offspring provisioning rate despite fluctuations in prey abundance: a 
multi-species functional response for guillemots in the North Sea. J. Appl. Ecol., 50, 1071-1079.

Thain, J.E., Vethaak, A.D., Hylland, K., 2008. Contaminants in marine ecosystems: developing an integrated indicator framework using biological-effect techniques. ICES J. Mar. Sci., 65, 1508-1514.

Trenkel, V.M., Berger, L., 2013. An acoustic multi-frequency index to inform on large scale spatial patterns of pelagic ecosystems. Ecol. Ind., 30, 72-79.

Trenkel, V.M., Daurès, F., Rochet, M.-J., Lorance, P., 2013. Interannual variability of fisheries economic returns and energy ratios is mostly explained by gear type. PLoS ONE, 8, e70165.

Trenkel, V.M., Ressler, P.H., Jech, M., Giannoulaki, M., Taylor, C., 2011. Underwater acoustics for ecosystem-based management: state of the science and proposals for ecosystem indicators. Mar. Ecol. Prog. Ser., 442, 285-301.

Trenkel, V.M., Huse, G., MacKenzie, B., Alvarez, P., Arrizabalaga, H., Castonguay, M., Goñi, N., Grégoire, F., Hátún, H., Jansen, T., Jacobsen, J.A., Lehodey, P., Lutcavage, M., Mariani, P., Melvin, G., Neilson, J.D., Nøttestad, L., Óskarsson, G.J., Payne, M., Richardson, D., Senina, I., Speirs, D.C., 2014. Comparative ecology of widelydistributed pelagic fish species in the North Atlantic: implications for modelling climate and fisheries impacts. Prog. Oceanog., 129B, 219-243.

Trenkel, V.M., Pinnegar, J.K., Dawson, W.A., du Buit, M.H., Tidd, A.N., 2005. Spatial and temporal structure of predator-prey relationships in the Celtic Sea fish community. Mar. Ecol. Prog. Ser., 299, 257-268.

Trites, A.W., Christensen, V., Pauly, D., 1997. Competition between fisheries and marine mammals for prey and primary production in the Pacific Ocean. J. Northwest Atlantic Fishery Science, 22, 173-187.

Tsagarakis, K., Vassilopoulou, V., Kallianiotis, A., Machias, A., 2012. Discards of the purse seine fishery targeting small pelagic fish in the eastern Mediterranean Sea. Scientia Marina, 76, 561-572.

Tuck, G.N., 2011. Are bycatch rates sufficient as the principal fishery performance measure and method of assessment for seabirds? Aquat. Conserv., 21, 412-422.

Vasilakopoulos, P., O'Neill, F.G., Marshall, C.T., 2012. Differential impacts of exploitation rate and juvenile exploitation on NE Atlantic fish stock dynamics over the past half century. Fish. Res., 134, 21-28. 
815 Wanless, S., Harris, M.P., Redman, P., Speakman, J.R., 2005. Low energy values of fish as a 816 probable cause of a major seabird breeding failure in the North Sea. Mar. Ecol. Prog. $817 \quad$ Ser., 294, 1-8.

818 Ward, P., Myers, R.A., 2005. Shifts in open-ocean fish communities coinciding with the 819 commencement of commercial fishing. Ecology, 86, 835-847. 
Figure 1. Framework linking strategic goals, ecological, social and economic management objectives, operational objectives and indicators for Northeast Atlantic pelagic ecosystems. Feedback processes may occur but were not addressed in this study (dashed lines).

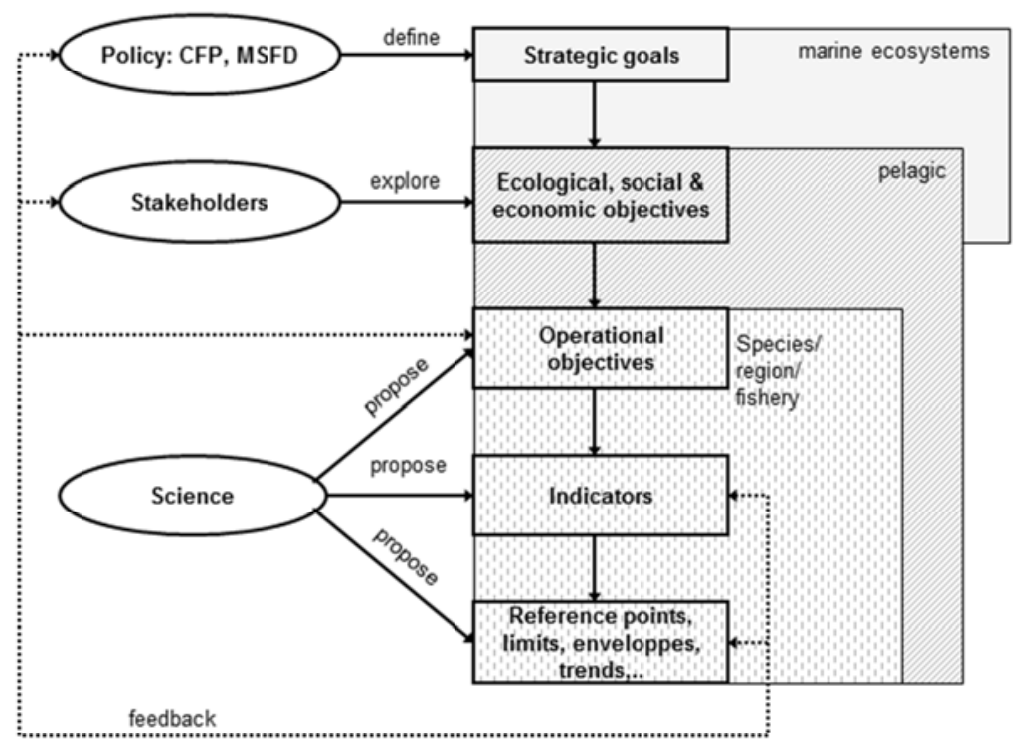


Figure 2. Schematic representation of marine pelagic ecosystem management objectives explored in this study. Circled numbers refer to objectives listed in table 1. Objectives fall into five categories: 1-3 societal values; 4-11 food web structure and flow; 12-17 fish population structure and flow; 18-22 habitat quality and quantity; 23-26 fishery yields.

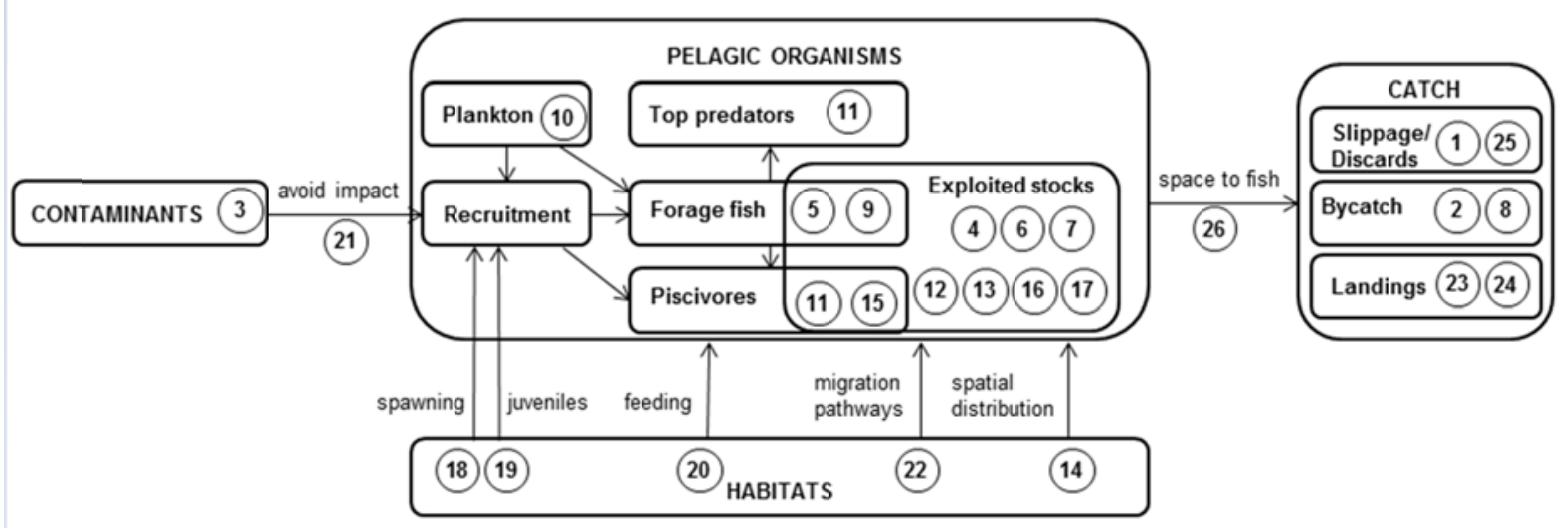


Table 1. Example operational objectives, indicators, reference levels and management actions for pelagic ecological, economic and social objectives identified by stakeholders. Category: C1 societal values, C2 food web structure and flow, C3 fish population structure and flow, C4 habitat quality and quantity, and C5 fishery yields.

Ecological level: C community, P population/stock, I individual.

\begin{tabular}{|c|c|c|c|c|c|c|c|}
\hline No & Category & Ecological objective & Level & $\begin{array}{l}\text { Example operational } \\
\text { objectives }\end{array}$ & Indicators & $\begin{array}{l}\text { Reference } \\
\text { levels }\end{array}$ & Management \\
\hline $\mathrm{O} 1$ & C1 & Limit slippage, discarding & C & $\begin{array}{l}\text { Limit discarding of } \\
\text { pelagic trawlers in Bay } \\
\text { of Biscay and North Sea }\end{array}$ & Discards/catch & $\begin{array}{l}\mathrm{x} \% \text { of total } \\
\text { catch }\end{array}$ & $\begin{array}{l}\text { Spatio-temporal } \\
\text { closures, gear rules, } \\
\text { TAC distribution } \\
\text { across vessels }\end{array}$ \\
\hline $\mathrm{O} 2$ & C1 & $\begin{array}{l}\text { Limit marine mammal, birds, } \\
\text { pelagic sharks, elasmobranchs } \\
\text { bycatch }\end{array}$ & C & See O8 & & & \\
\hline $\mathrm{O} 3$ & C1 & $\begin{array}{l}\text { Achieve low level of } \\
\text { contaminants from land }\end{array}$ & C & $\begin{array}{l}\text { Limit contamination by } \\
\text { dioxins and dioxin-like } \\
\text { PCBs in Baltic Sea } \\
\text { herring }\end{array}$ & $\begin{array}{l}\text { Dioxins and } \\
\text { dioxin-like PCB } \\
\text { concentration in } \\
\text { herring }\end{array}$ & $\begin{array}{l}\text { Sum of dioxins } \\
\text { and } \\
\text { dioxin-like } \\
\text { PCBs }<8 \text { pg/g } \\
\text { wet weight (EC, } \\
\text { 2006) }\end{array}$ & $\begin{array}{l}\text { Regulate polluting } \\
\text { terrestrial activities }\end{array}$ \\
\hline $\mathrm{O} 4$ & $\mathrm{C} 2$ & Maintain exploited stocks & $\mathrm{P}$ & $\begin{array}{l}\text { Maintain stock biomass } \\
\text { and exploitation rate } \\
\text { within safe biological } \\
\text { limits }\end{array}$ & $\begin{array}{l}\text {-Stock biomass } \\
\text {-Exploitation rate } \\
\text { relative to } \\
\text { biological } \\
\text { reference point }\end{array}$ & $\begin{array}{l}\text { Biological } \\
\text { reference points } \\
\text { ensuring no } \\
\text { impairment of } \\
\text { recruitment, e.g. } \\
\text { SSB }_{\text {lim }}, \mathrm{F}_{\mathrm{PA}}\end{array}$ & TAC \\
\hline O5 & $\mathrm{C} 2$ & $\begin{array}{l}\text { Maintain food supply for higher } \\
\text { trophic levels }\end{array}$ & C & $\begin{array}{l}\text { Maintain herring and } \\
\text { sprat biomass in the } \\
\text { Baltic for cod; } \\
\text { Maintain sandeel } \\
\text { biomass in the North Sea } \\
\text { for seabird predators }\end{array}$ & $\begin{array}{l}\text { Prey biomass or F; } \\
\text { Predator } \\
\text { condition/growth/ } \\
\text { productivity }\end{array}$ & $\begin{array}{l}>\mathrm{X} \text { tons of prey } \\
\text { species }\end{array}$ & TAC \\
\hline O6 & $\mathrm{C} 2$ & $\begin{array}{l}\text { Maintain functional diversity in } \\
\text { the pelagic system }\end{array}$ & C & $\begin{array}{l}\text { Manage all exploited } \\
\text { pelagic fish stocks } \\
\text { sustainably; } \\
\text { Improve red listed } \\
\text { marine mammals and } \\
\text { turtles }\end{array}$ & $\begin{array}{l}\text {-Biomass/ } \\
\text { abundance } \\
\text { - Fishing mortality }\end{array}$ & $\begin{array}{l}\text { Bmsy; Fmsy; } \\
\text { IUCN criteria }\end{array}$ & $\begin{array}{l}\text { TAC, Reduce } \\
\text { bycatch using gear } \\
\text { devices }\end{array}$ \\
\hline O7 & $\mathrm{C} 2$ & Maintain structural biodiversity & C & See objective 6 & & & \\
\hline 08 & $\mathrm{C} 2$ & $\begin{array}{l}\text { Limit marine mammal, birds, } \\
\text { pelagic sharks, elasmobranchs } \\
\text { bycatch }\end{array}$ & P & $\begin{array}{l}\text { Reduce marine mammal } \\
\text { and bird bycatch in } \\
\text { bluefin tuna fisheries }\end{array}$ & - Bycatch rate & $\mathrm{x}$ individuals & $\begin{array}{l}\text { Spatio-temporal } \\
\text { closures, escape } \\
\text { devices/pingers }\end{array}$ \\
\hline O9 & $\mathrm{C} 2$ & $\begin{array}{l}\text { Maintain prey diversity in the } \\
\text { diet of predator } x\end{array}$ & $\mathrm{P}$ & None & & & \\
\hline O10 & $\mathrm{C} 2$ & $\begin{array}{l}\text { Maintain functional plankton } \\
\text { community }\end{array}$ & C & None & & & \\
\hline
\end{tabular}




\begin{tabular}{|c|c|c|c|c|c|c|c|}
\hline O11 C? & & $\begin{array}{l}\text { Predator of pelagic resource } \\
\text { condition and growth rate }\end{array}$ & $P$ & $\begin{array}{l}\text { Maintain reproductive } \\
\text { success of great skua, } \\
\text { European shag and } \\
\text { common guillemot in } \\
\text { North Sea }\end{array}$ & $\begin{array}{l}\text { Number of chicks } \\
\text { fledged per nest }\end{array}$ & $\begin{array}{l}\text { x chicks } \\
\text { fledged per nest }\end{array}$ & $\begin{array}{l}\text { Adjust local sandeel } \\
\text { catches }\end{array}$ \\
\hline \begin{tabular}{|l|l|l}
$\mathrm{O} 12$ & $\mathrm{C}$
\end{tabular} & C3 & $\begin{array}{l}\text { Maintain the stock component } \\
\text { diversity }\end{array}$ & $P$ & $\begin{array}{l}\text { Maintain all herring } \\
\text { spawning stock } \\
\text { components }\end{array}$ & $\begin{array}{l}\text { - SSB for each } \\
\text { herring spawning } \\
\text { component }\end{array}$ & SSBlim & $\begin{array}{l}\text { Area \& season } \\
\text { based quotas }\end{array}$ \\
\hline O13 C? & C3 & $\begin{array}{l}\text { Maintain a healthy age } \\
\text { distribution of the pelagic fish } \\
\text { community }\end{array}$ & $P$ & $\begin{array}{l}\text { Maintain age structure } \\
\text { in sardine stocks in } \\
\text { European waters }\end{array}$ & $\begin{array}{l}\text {-Abundance/ } \\
\text { proportion of fish } \\
\text { that are older than } \\
\text { age-at-maturity } \\
- \text { F }_{\text {immature }} / F_{\text {mature }}\end{array}$ & $\begin{array}{l}\text { Long-term } \\
\text { mean }\end{array}$ & $\begin{array}{l}\text { TAC and fishery } \\
\text { size selection } \\
\text { pattern }\end{array}$ \\
\hline $\mathrm{O} 14 \mathrm{C}$ & $\overline{\mathrm{C} 3}$ & $\begin{array}{l}\text { Maintain spatial distribution of } \\
\text { pelagic fish }\end{array}$ & $P$ & $\begin{array}{l}\text { None as factors not } \\
\text { understood }\end{array}$ & & & \\
\hline $\mathrm{O} 15 \mathrm{C}^{2}$ & $\overline{\mathrm{C} 3}$ & $\begin{array}{l}\text { Maintain body condition / } \\
\text { growth rate / age at maturity }\end{array}$ & I & See objectives 5 \& 11 & & & \\
\hline O16 & & Maintain genetic diversity & $P$ & $\begin{array}{l}\text { Avoid overly selective } \\
\text { fishing of any species }\end{array}$ & $?$ & & \\
\hline O17 C? & C3 & $\begin{array}{l}\text { Maintain phenotypic width / } \\
\text { breadth }\end{array}$ & $P$ & None & & & \\
\hline $\mathrm{O} 18 \mathrm{C}$ & & Maintain spawning habitat & $P$ & $\begin{array}{l}\text { Maintain herring } \\
\text { spawning habitat; } \\
\text { Maintain capelin } \\
\text { spawning habitat }\end{array}$ & $\begin{array}{l}\text { Size of suitable } \\
\text { spawning habitat }\end{array}$ & 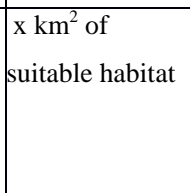 & $\begin{array}{l}\text { Limit gravel } \\
\text { extraction/habitat } \\
\text { destruction }\end{array}$ \\
\hline $\mathrm{O} 19 \mathrm{C}$ & $\mathrm{C} 4$ & Maintain juvenile habitat & $P$ & None & & & \\
\hline $\mathrm{O} 20 \mid \mathrm{C}$ & $\overline{\mathrm{C} 4}$ & Maintain feeding habitat & $P$ & None & & & \\
\hline $\mathrm{O} 21 \mathrm{C}$ & $\overline{\mathrm{C} 4}$ & $\begin{array}{l}\text { Limit contaminants that effect } \\
\text { recruitment success }\end{array}$ & $P$ & None & & & \\
\hline $\mathrm{O} 22 \mathrm{C}$ & & Maintain migration ways & $P$ & $\begin{array}{l}\text { Ensure potential } \\
\text { migration ways are not } \\
\text { increasingly impacted by } \\
\text { bridges, dams, etc. }\end{array}$ & $\begin{array}{l}\text { Proportion of } \\
\text { migration ways } \\
\text { impacted by } \\
\text { physical constructs }\end{array}$ & $\begin{array}{l}\text { x\% migration } \\
\text { ways impacted }\end{array}$ & Spatial planning \\
\hline $\mathrm{O} 23 \mathrm{C}$ & & Optimize yield & $P$ & $\begin{array}{l}\text { Interannual stability of } \\
\text { landings }\end{array}$ & $\begin{array}{l}\text { Interannual } \\
\text { variance of } \\
\text { landings }\end{array}$ & $\begin{array}{l}\mathrm{X} \text { landings, } \\
\mathrm{X} \% \text { change in } \\
\text { landings }\end{array}$ & $\begin{array}{l}\text { constant TAC, } \\
\text { capped TAC change }\end{array}$ \\
\hline $\mathrm{O} 24 \mathrm{C}^{\mathrm{t}}$ & & Maximise sustainable yield & $\mathrm{P}$ & $\begin{array}{l}\text { Stock management } \\
\text { compatible with MSY }\end{array}$ & Fishing mortality & $F_{M S Y}$ & TAC, etc. \\
\hline $\mathrm{O} 25 \mathrm{C}$ & 65 & Limit slippage, discarding & $P$ & $\begin{array}{l}\text { Limit slippage and } \\
\text { discarding of herring, } \\
\text { blue whiting and } \\
\text { mackerel in North Sea; } \\
\text { Limit discarding of } \\
\text { anchovy in Bay of } \\
\text { Biscay }\end{array}$ & $\begin{array}{l}\text { Discards/catch per } \\
\text { species; } \\
\text { Slippage/catch }\end{array}$ & $\begin{array}{l}\mathrm{x} \% \text { of species } \\
\text { catch }\end{array}$ & \begin{tabular}{|l|} 
Spatio-temporal \\
closures, gear rules, \\
TAC distribution \\
across vessels
\end{tabular} \\
\hline $\mathrm{O} 26 \mathrm{C}$ & $\mathrm{C5}$ & Maintain physical space to fish & C & $\begin{array}{l}\text {-Maintain space to fish } \\
\text { for pelagic fisheries in } \\
\text { North Sea }\end{array}$ & $\begin{array}{l}\text {-Size of suitable } \\
\text { fishing areas }\end{array}$ & $\begin{array}{l}\mathrm{x} \mathrm{km}^{2} \text { of } \\
\text { suitable fishing } \\
\text { area }\end{array}$ & Spatial planning \\
\hline
\end{tabular}


Identifying marine pelagic ecosystem objectives and indicators for management

\section{Supplementary Material}

Table S1. List of ecological pelagic ecosystem objectives resulting from two workshops held in 2013. Other stakeholders included representatives from management, fishing industry and one NGO. Categories: $\mathrm{C} 1$ societal value (non-use value); $\mathrm{C} 2$ structure and flow of the food webs; C3 structure and flow within fish populations; C4 habitat quantity and quality; C5 fisheries yields.

\begin{tabular}{|c|c|c|c|c|c|}
\hline Category & No & Objective & Scientists & $\begin{array}{c}\text { Other } \\
\text { stakeholders }\end{array}$ & $\begin{array}{c}\text { Responsive to } \\
\text { management } \\
\text { F: Fisheries } \\
\text { O: Other }\end{array}$ \\
\hline C1 & 1 & Limit slippage, discarding & $\mathrm{x}$ & $\mathrm{x}$ & $\mathrm{F}$ \\
\hline C1 & 2 & $\begin{array}{l}\text { Limit marine mammal, birds, pelagic sharks, elasmobranchs } \\
\text { bycatch }\end{array}$ & $\mathrm{x}$ & $\mathrm{x}$ & $\mathrm{F}$ \\
\hline $\mathbf{C 1}$ & 3 & Achieve low level of contaminants from land & & $\mathrm{x}$ & $\mathrm{O}$ \\
\hline $\mathbf{C 2}$ & 4 & Maintain exploited stocks & $\mathrm{x}$ & & $\mathrm{F}$ \\
\hline $\mathbf{C 2}$ & 5 & Maintain food supply for higher trophic levels & $\mathrm{x}$ & $\mathrm{x}$ & $\mathrm{F}$ \\
\hline $\mathbf{C 2}$ & 6 & Maintain functional diversity in the pelagic system & $\mathrm{x}$ & $\mathrm{x}$ & $\mathrm{F}$ \\
\hline $\mathbf{C 2}$ & 7 & Maintain structural biodiversity & $\mathrm{x}$ & $\mathrm{x}$ & $\mathrm{F}$ \\
\hline $\mathbf{C 2}$ & 8 & $\begin{array}{l}\text { Limit marine mammal, birds, pelagic sharks, elasmobranchs } \\
\text { bycatch }\end{array}$ & $\mathrm{x}$ & $\mathrm{x}$ & $\bar{F}$ \\
\hline $\mathbf{C 2}$ & 9 & Maintain prey diversity in the diet of predator $x$ & $\mathrm{x}$ & & $\mathrm{F}^{*}$ \\
\hline $\mathbf{C 2}$ & 10 & Maintain functional plankton community & & $\mathrm{x}$ & $\mathrm{O} * *$ \\
\hline $\mathbf{C 2}$ & 11 & Predator of pelagic resource condition and growth rate & & $\mathrm{x}$ & $\mathrm{F}^{*}$ \\
\hline $\mathbf{C 3}$ & 12 & Maintain the stock component diversity & $\mathrm{x}$ & & $\mathrm{F}$ \\
\hline$\overline{\mathbf{C 3}}$ & 13 & Maintain a healthy age structure of the pelagic fish community & $\mathrm{x}$ & & $\bar{F}$ \\
\hline$\overline{\mathbf{C 3}}$ & 14 & Maintain a spatial distribution of pelagic fish & $\mathrm{x}$ & $\mathrm{x}$ & $\bar{F}$ \\
\hline $\mathbf{C 3}$ & 15 & Maintain body condition / growth rate / age at maturity & $\mathrm{x}$ & $\mathrm{x}$ & $\mathrm{F}$ \\
\hline $\mathbf{C 3}$ & 16 & Maintain genetic diversity & $\mathrm{x}$ & $\mathrm{x}$ & $\mathrm{F}$ \\
\hline $\mathbf{C 3}$ & 17 & Maintain phenotypic width / breadth & $\mathrm{x}$ & & $\mathrm{F}$ \\
\hline $\mathbf{C 4}$ & 18 & Maintain spawning habitat & $\mathrm{x}$ & $\mathrm{x}$ & $\mathrm{O}$ \\
\hline $\mathbf{C 4}$ & 19 & Maintain juvenile habitat & $\mathrm{x}$ & $\mathrm{x}$ & $\mathrm{F}, \mathrm{O}$ \\
\hline $\mathbf{C 4}$ & 20 & Maintain feeding habitat & $\mathrm{x}$ & $\mathrm{x}$ & $\mathrm{O}$ \\
\hline $\mathbf{C 4}$ & 21 & Limit contaminants that effect recruitment success & $\mathrm{x}$ & $\mathrm{x}$ & $\mathrm{O}$ \\
\hline $\mathbf{C 4}$ & 22 & Maintain migration ways & $\mathrm{x}$ & & $\mathrm{O}$ \\
\hline $\mathbf{C 5}$ & 23 & Optimize yield & $\mathrm{x}$ & $\mathrm{x}$ & $\bar{F}$ \\
\hline $\mathbf{C 5}$ & 24 & Maximise sustainable yield & $\mathrm{x}$ & $\mathrm{x}$ & $\mathrm{F}$ \\
\hline $\mathbf{C 5}$ & 25 & Limit slippage, discarding & $\mathrm{x}$ & & $\mathrm{F}$ \\
\hline $\mathbf{C 5}$ & 26 & Maintain physical space to fish & & $\mathrm{x}$ & $\mathrm{O}$ \\
\hline
\end{tabular}

*When strong links exist between fish abundance and fishing and between fish abundance and predator food intake

**When strong links exist between e.g. nutrient run-off and composition of the plankton community 
Table S2. List of the small, medium and large pelagic fish stocks exploited and managed (*) in Northeast Atlantic and Mediterranean Sea (>1000 t per year according to FAO).

Pelagic species groups: SP small pelagics; MP medium-sized pelagics; LP large pelagics.

ICES International Council for the Exploration of the Sea (quota advice); GCFM General Fisheries Commission for the Mediterranean Sea (technical measures only); ICCAT International Commission for the Conservation of Atlantic Tunas (quota advice).

\begin{tabular}{|c|c|c|c|c|}
\hline Name & English name & Group & Exploited areas (stocks) & $\begin{array}{l}\text { Advice } \\
\text { organisation }\end{array}$ \\
\hline Ammodytes spp. & Sand eel & $\mathrm{SP} * *$ & North Sea (several) & ICES \\
\hline Atherina spp. & Sand smelts & $\mathrm{SP}$ & Mediterrannean & GFCM* $^{*}$ \\
\hline Engraulis encrasicolus & Anchovy & SP & Bay of Biscay, Mediterranean & ICES, GFCM \\
\hline Mallotus vilosus & Capelin & SP & Barents Sea, Iceland/Greenland & ICES \\
\hline Micromestitius poutassou & Blue whiting & SP & NE Atlantic & ICES \\
\hline Sardina pilchardus & European pilchard & SP & $\begin{array}{l}\text { Bay of Biscay, Iberian } \\
\text { peninsula, Mediterrannean }\end{array}$ & ICES\$, GFCM \\
\hline Sardinella aurita & Round sardinella & SP & Mediterrannean & GFCM* $^{*}$ \\
\hline Spicara smaris & Picarel & SP & Mediterrannean & $\mathrm{GFCM}^{*}$ \\
\hline Sprattus sprattus & European sprat & SP & $\begin{array}{l}\text { Baltic Sea, North Sea, } \\
\text { Mediterranean }\end{array}$ & ICES, GFCM \\
\hline Auxis rochei & Bullet tuna & MP & Atlantic, Mediterrannean & ICCAT§ \\
\hline Auxis thazard & Fregate tuna & MP & Atlantic & ICCAT \\
\hline Belone belone & Garfish & MP & Atlantic, Mediterrannean & GFCM* $^{*}$ \\
\hline Brama brama & Atlantic pomfret & MP & Atlantic, Mediterrannean & GFCM $^{*}$ \\
\hline Clupea harengus & Atlantic herring & MP & $\begin{array}{l}\text { Norwegian spring-spawners, } \\
\text { Celtic Sea, Irish Sea, North Sea } \\
\text { autumn spawners, }\end{array}$ & ICES \\
\hline Euthynnus alletteratus & Little tunny & MP & Atlantic, Mediterrannean & ICCAT \\
\hline Ocrynopsis unicolor & Plain bonito & MP & Atlantic, Mediterrannean & ICCAT§ \\
\hline Pomatomus saltatrix & Bluefish & MP & Mediterrannean & GFCM* \\
\hline Sarda sarda & Atlantic bonito & MP & Atlantic, Mediterrannean & ICCAT§ \\
\hline Scomber colias & $\begin{array}{l}\text { Atlantic chub } \\
\text { mackerel }\end{array}$ & MP & Mediterrannean & $\mathrm{GFCM}^{*}$ \\
\hline Scomber scombrus & Atlantic mackerel & MP & NE Atlantic, Mediterrannean & ICES \\
\hline Trachurus mediterraneus & $\begin{array}{l}\text { Mediterranean } \\
\text { horse mackerel }\end{array}$ & MP & NE Atlantic ,Mediterrannean & GFCM \\
\hline Trachurus picturatus & Blue jack mackerel & MP & Mediterrannean & GFCM \\
\hline Trachurus trachurus & $\begin{array}{l}\text { Altantic horse } \\
\text { mackerel }\end{array}$ & MP & North Sea, Mediterrannean & ICES, GFCM \\
\hline Thunnus atlanticus & Blackfin tuna & MP & Atlantic, Mediterrannean & ICCAT\$ \\
\hline Coryphaena hippurus & $\begin{array}{l}\text { Common } \\
\text { dolphinfish }\end{array}$ & LP & Mediterrannean & GFCM* \\
\hline Istiophorus albicans & Sailfish & LP & East Atlantic & ICCAT \\
\hline Katsuwonus pelamis & Skipjack tuna & LP & NE Atlantic & ICCAT \\
\hline Makaira nigricans & Atlantic blue marlin & LP & North Atlantic & ICCAT \\
\hline Seriola dumerili & Greater amberjack & LP & Mediterrannean & GFCM* $^{*}$ \\
\hline Sphyraena sphyraena & European baracuda & LP & Mediterrannean & $\mathrm{GFCM}^{*}$ \\
\hline Tetrapturus albidus & $\begin{array}{l}\text { Atlantic white } \\
\text { marlin }\end{array}$ & $\overline{\mathrm{LP}}$ & North Atlantic§ & ICCAT \\
\hline Thunnus alalunga & Albacore & LP & North Atlantic, Mediterranean & ICCAT \\
\hline Thunnus albacares & Yellowfin tuna & LP & Atlantic & ICCAT \\
\hline Thunnus obesus & Bigeye tuna & LP & Atlantic & ICCAT \\
\hline Thunnus thynnus & Bluefin tuna & LP & NE Atlantic incl. Mediterranean & ICCAT \\
\hline Xiphia gladius & Swordfish & LP & North Atlantic, Mediterranean & ICCAT \\
\hline
\end{tabular}

